\title{
Capital Markets for Small- and Medium-sized Enterprises and Startups in Korea*
}

\author{
Ki Beom BINH ${ }^{1}$, Hogyu JHANG ${ }^{2}$, Daehyeon PARK ${ }^{3}$, Doojin RYU ${ }^{4}$
}

Received: September 01, 2020 Revised: October 26, 2020 Accepted: November 05, 2020

\begin{abstract}
This study describes the structure of the capital markets for small- and medium-sized enterprises (SMEs) and startup companies in Korea, which is an emerging market that has experienced drastic changes. The overall capital market can be divided into private and public capital markets. In the private capital market, most of the demand for capital comes from non-listed private firms, including startups and SMEs. In the case of SMEs and startups, the KOSDAQ, the Korea New Exchange (KONEX), and primary collateralized bond obligations (P-CBOs) are part of the public capital market. SMEs and startups are generally incapable of raising sufficient capital owing to their low credit ratings, and they largely have limited access to primary markets to issue shares and borrow money. The Korean government has developed a systematic financial aid program to provide funds to these companies. The fund for SMEs has significantly contributed to the development of the venture capital market. Many Korean banks provide substantial lending to SMEs, but this lending is available only because of the Korean government's loan recovery guarantee. Furthermore, SMEs can issue corporate debt in the form of primary collateralized bond obligations through government guarantees, but such debt issuances have placed increasing pressure on public guarantee institutions.
\end{abstract}

Keywords: Capital Market, Emerging Market, Government-sponsored Venture Capital, Loan Guarantee, Primary Collateralized Bond Obligation, Small- and Medium-sized Enterprises

JEL Classification Code: G24, G28, H81, M13

\section{Introduction}

Fostering small- and medium-sized enterprises (SMEs) and startup companies (startups, hereafter) is important for

\footnotetext{
*Acknowledgments:

[1] The authors are presented in alphabetical order. Hogyu Jhang is the main (primary) author of this paper.

${ }^{1}$ First Author. Professor, Department of Economics, Myongji University, Seoul, Korea. Email: bink1@mju.ac.kr

${ }^{2}$ Professor, School of Business, Chungnam National University, Daejeon, Korea. Email: jhogyu@gmail.com

${ }^{3} \mathrm{PhD}$ Candidate, College of Economics, Sungkyunkwan University, Seoul, Korea. Email: pdh829@skku.edu

${ }^{4}$ Corresponding Author. Professor, College of Economics,

Sungkyunkwan University, Seoul, Korea [Postal Address: College of

Economics, Sungkyunkwan University, 25-2, Sungkyunkwan-ro,

Jongno-gu, Seoul, 03063, Korea] Email: sharpjin@skku.edu

(C) Copyright: The Author(s)

This is an Open Access article distributed under the terms of the Creative Commons Attribution Non-Commercial License (https://creativecommons.org/licenses/by-nc/4.0/) which permits unrestricted non-commercial use, distribution, and reproduction in any medium, provided the original work is properly cited.
}

emerging economies to achieve sustainable growth. Because SMEs' capital constraints and information asymmetry hinder optimal capital procurement in society, helping them to procure capital can greatly improve economic growth (Clementi \& Hopenhayn, 2006; Ćorić, 2010; Mauzu \& Ogujiuba, 2020; Rossi \& Fattoruso, 2017; Stiglitz, 1981; Sumiati, 2020). South Korea is an emerging market that has experienced drastic changes, including rapid growth, decline, and recovery. Immediately after the Korean War, it was one of the poorest countries, but it now ranks around tenth in terms of trade volume and GDP. Almost every leader in the Korean government has emphasized the importance of SME and startup growth, and this policy stance has continued for many years to this day. South Korea's constitution explicitly mentions the democratization of the economy, and it includes such articles as "the country should exert all the effort in nurturing SMEs."

The Korean government has placed greater emphasis on setting economic policies to cultivate SMEs since the Asian financial crisis in 1997. However, the major goal of these policies has changed from supporting SMEs in general to facilitating the cultivation and growth of SMEs and startups with frontier technologies. In the early 2000 s, many information technology (IT) startups were listed 
on the Korean Securities Dealers Automated Quotations (KOSDAQ) and benefited from price appreciation. At that time, the new economy was the central theme, whereas today, the Fourth Industrial Revolution is the central economic theme. Despite the collapse of the IT bubble in 2000, South Korea's IT infrastructure and services are well- developed. South Korean policy continues to enable the easy identification and support of SMEs and startups that pursue cutting-edge technology, and these policies fostering SMEs have been important to South Korea's economic growth. South Korea has tried to set up an organic, complex financial system to support SMEs and startups. To this end, the system is improving efficiency, as the government has made major financial investments. The Korean government continues to strongly implement policies to support SMEs to ensure the sustainable growth of the Korean economy. Thus, Korea's policies regarding SMEs and startups may serve as helpful references for other emerging markets. Accordingly, this study describes Korea's policies for SMEs and startups.

This study focuses on Korea's capital market. ${ }^{1}$ The overall capital market can be divided into private and public capital markets (see Figure 1). In the private capital market, most of the demand for capital comes from nonlisted private firms, including startups and SMEs. ${ }^{2}$ The private capital market is not different from the private equity (PE) market, and SMEs and startups can obtain funds from venture capital (VC) or PE. However, in Korea, the primary resources that are invested in SMEs are public funds in the form of governmental loans or investments. The public capital market usually refers to both the regular and over-the-counter fixed income markets and the regular stock exchange. Publicly held or bond-issuing firms are the primary demanders of capital in this market.

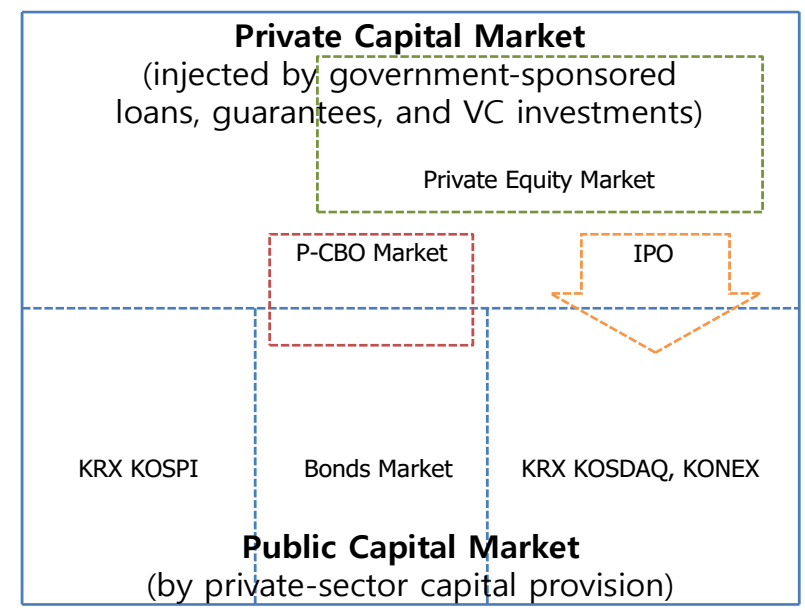

Figure 1: Private vs. public capital markets in Korea
In the case of SMEs and startups, the KOSDAQ, the Korea New Exchange (KONEX), and primary collateralized bond obligations (P-CBOs) are part of the public capital market. Initially, the KOSDAQ was the only stock market available for SMEs. However, as its listing requirements have become more stringent, listing on this exchange has become virtually impossible for small companies or startups. The KONEX, which has fewer requirements, was therefore established as the result of a governmental policy decision. ${ }^{3}$ It is well known that the private capital market cannot achieve continued economic growth solely by cultivating SMEs and startups because of market failure. Even in the US, where the private capital market plays a dominant role in SMEs' capital-raising process, the government runs the Small Business Investment Company (SBIC) program to facilitate the flow of long-term capital to small businesses. P-CBOs' resources are not fully private, as they include credit guarantees from the government.

The remainder of this paper is organized as follows. We provide an overview of Korea's capital market for SMEs and startups in Section 2. We then present more details about Korea's private and public capital markets in Sections 3 and 4, respectively. Section 5 concludes.

\section{Outline of Capital Markets of SMEs and Startups in Korea}

In general, enterprises need to continually raise capital throughout their lifetimes. With only capital from their founders and associates of their founders, firms face limits on their ability to grow. Facing further capital needs, firms often make initial public offerings (IPOs), through which they can raise substantial amounts of capital from outside investors (Berger \& Udell, 2006; Carbo-Valverde et al., 2016; Harjadi et al., 2020; Nguyen, 2020). Although making an IPO and listing on a stock exchange are not precisely the same actions, they are usually regarded as being the same. Typically, a firm's stock is traded publicly after it makes an IPO. Startups and new firms do not make IPOs impulsively but rather take subsidiary-like public funds from the government or obtain funds from $\mathrm{VC}$ or $\mathrm{PE}$ firms before choosing to make an IPO. Depending on an invested firm's needs, VC and PE firms intervene with or actively monitor management; VC (or PE) firms' interests do not conflict with managers' interests because both primarily seek to boost firm value. Thus, both parties may want to go public after some amount of time. In terms of the return on investment, outside investors prefer IPOs more strongly owing to their investment schedules, by which they exit their current investments (by obtaining their target rates of investment) and move to other investment opportunities. 
VC funds tend to carry out venture firm investments using capital from the government-sponsored VC fund, which serves as a public parent fund for private venture capitalists (Berger \& Schaeck, 2011; Rossi \& Martini, 2019; Udell, 2015). Brander et al. (2015) report that over $50 \%$ of the enterprises that they identify in their study are supported by government-sponsored VC (GVC). They argue that GVC augments private VC finance. GVC-aid investments are characterized as governmental support, meaning that exiting the invested capital on time is extremely important for i) the successful recovery of government spending and ii) the appropriate use of taxes (Ayyagari et al., 2014; Berger \& Udell, 2006). Moreover, these exits allow the founding owner of a startup or small enterprise to increase his or her stake in the company, providing another economic benefit.

A major instrument for redeeming invested funds, in the long run, is listing a firm on the KOSDAQ or KONEX. The KOSDAQ and KONEX are two important stock markets in which SMEs with limited capital-raising abilities can participate. These markets were established with the help of Korean financial authorities. In the medium run, a VC firm can choose another option, such as selling an invested firm to strategic investors through mergers and acquisitions (M\&A) in what is known as a trade sale. VC firms can be sold to other VC or PE firms through secondary trades in which the buyer VC or PE firm will most likely go public at a later time. In Korea, however, the markets for private capital and M\&As are less developed, and secondary trades and M\&A activities occur infrequently. Thus, most $\mathrm{VC}$ firms tend to focus on listing their invested firms on the KOSDAQ or the KONEX.

Currently, the Korea Exchange (KRX) is Korea's regular stock exchange, which monopolistically provides trading and settlement services to traders. ${ }^{4}$ The KRX runs three different stock markets - the Korea Composite Stock Price Index (KOSPI), KOSDAQ, and KONEX - as well as futures and options exchanges. ${ }^{5}$ Korea's main regular stock exchange first opened in the 1960s, and the KOSDAQ board opened in $1996 .{ }^{6}$ The main objective of the KOSDAQ's establishment was to help SMEs raise capital. In the US, the NASDAQ, which emerged long after the New York Stock Exchange (NYSE) was established, represents innovative, high-tech firms. Although firms listed on the NASDAQ are typically smaller than firms listed on the NYSE, the NASDAQ successfully competes with the NYSE based on its own characteristics. Likewise, the KOSDAQ began with the purpose of representing high-tech, innovative firms. In 1996, many high-tech firms attracted investor attention after being listed on the KOSDAQ. As a result, many institutional and individual investors started trading on the KOSDAQ, pushing the
KOSDAQ index from its initial value of 1,000 to 2,500 by 2000 . However, the IT bubble bursts in the same year, and the index plunged to 500. Since then, many breaches of trust, embezzlement, and price manipulation cases have arisen, leading to stronger listing requirements to protect investors. Owing to these stricter requirements, many startups have had difficulty going public. The KOSDAQ became the capital market for so-called "enterprises of middle standing," which are not entirely the same as SMEs. Typical KOSDAQ firms differ from the ordinary large enterprises on the KOSPI, but they also differ significantly from other SMEs. For example, whereas the average time until listing was 9.3 years in 2004, it reached 13.3 years on average as of $2011 .^{7}$

Because launching an IPO on the KOSDAQ has become difficult for many small enterprises and startups and because M\&As are also fairly limited, VC firms have no effective divestment method. Therefore, this difficulty in making an IPO is a significant impediment to establishing a virtuous cycle of capital in Korea's overall venture ecosystem. The government could have relaxed the KOSDAQ's stronger IPO restrictions. However, it chose a different option, leading to the establishment of the KONEX in the year 2013, which has much fewer listing requirements. ${ }^{8}$

Corporate bonds are as important capital market instruments as stocks are. Bank loans and bonds are similar in the sense that both instruments enable the borrowing and lending of money. However, issuing bonds allows a firm to raise more capital from many different investors. Unlike bank loans, bonds are easily traded in the inter-dealer secondary market. Of course, banks can repackage their loans into new securities, such as asset-backed securities (ABS), that can also be traded in the market. However, bondholders do not require firms to repay their debts earlier because bondholders can sell their bonds in the market. ${ }^{9}$ Thus, firms can freely use the money raised from issuing bonds with no liability until the bonds' maturity dates; this capital is usually used for investments in fixed assets or R\&D (Berger \& Udell, 1995, 1998; Giacosa et al., 2016; Rossi, 2014).

Despite these advantages, however, issuing bonds is not an easy way to raise capital in Korea. Even large enterprises struggle to issue bonds, mainly because finding investors is difficult; hence, in Korea, large firms' bonds are usually taken over by the Korea Development Bank (KDB) or the Export-Import Bank of Korea, which are governmentowned banks. Thus, bond issuance is not a viable way for SMEs to raise capital. In most cases, the only truly viable option is bank loans, although some rare exceptions include angel or accelerator investments for startups..$^{10}$ To mitigate this situation, P-CBOs were introduced in 2000 to encourage SMEs and startups to issue bonds to 
flexibly raise long-term capital. Specifically, P-CBOs are securities based on a pool of newly-issued SME bonds and are provided with further credit guarantees by the Korean government.

\section{Private Capital Markets and Government Support for SMEs and Startups in Korea}

SMEs and startups mainly raise capital through the private capital market, in which the Korean government is the primary provider of capital. Thus, SMEs and startups usually raise capital through direct or indirect investments and governmental credit guarantees. Once such firms list themselves on the KOSDAQ or KONEX by going public, they enter the public capital market.

The debt capital of non-listed SMEs and startups mainly comes from bank lending. Such firms usually have low credit ratings, and, thus, their debt capital takes the form of a guaranteed loan. In Korea, the Korea Credit Guarantee Fund (KODIT) and the Korea Technology Finance Corporation (KIBO) provide credit guarantees for firms. About $50 \%$ of bank loans provided to SMEs and startups come from the Industrial Bank of Korea (IBK), which is a governmentowned bank. Additionally, firms that have extremely low credit ratings and cannot obtain bank loans or guarantees from governmental agencies can raise small amounts of money through another governmental agency, the Korea SMEs and Start-ups Agency (KOSME), even without a guarantee. Furthermore, loan guarantees from governmental agencies play a very critical role within the governmentsponsored SME financing system. For example, the SBIC in the US is also a large-budget governmental guarantee program for licensed private $\mathrm{VC}$ funds to finance bank loans. Brewer et al. (1996) divide SBIC funds' resources into self- funded equity capital and loans guaranteed by the SBIC program. Brown and Earle (2017) find that Small Business Association 7(a) and 504 loan programs, which also have partial (50-80\%) loan guarantee schemes, have positive job- creating effects.

As mentioned before, SMEs and startups find it difficult to issue bonds directly in the capital market, and $\mathrm{P}-\mathrm{CBO}$ are a complementary tool under such constraints. Even P-CBOs need guarantees to enhance these firms' credit, and the KIBO and the KODIT provide these guarantees. In summary, the Korean government plays an essential role in providing loans and guarantees for SMEs and startups. Funding for these firms usually takes place through a private market in which its main resources are from public funds.

As in the case of bonds, it is practically impossible for SMEs and startups to issue stocks by themselves. Even the capital increase provided by seasoned (non-listed) equity offerings through the help of the known associates of a firms' founders is small or negligible. Angel investors and accelerators are professional investors who are not known associates. Although they are venture capitalists in a broad sense, their firms need to raise capital from more typical venture capitalists. PE is at the core of private capital market funds. VC firms play a significant role in funding SMEs and startups, ${ }^{11}$ and they usually try to find and cultivate high-potential startups. A good example of success for a VC firm is exiting its investment through an IPO on the KOSDAQ or the KONEX. Thus, a startup venture SME's transition from the private to the public capital market largely depends on the VC firm's capabilities. As Figure 2 shows, an IPO is the best way for a $\mathrm{VC}$ firm to exit an invested private firm, as the VC firm can harvest profits from the investment and complete its engagement. However, $\mathrm{VC}$ investments from the private capital market are not sufficient to nurture many startup ventures and SMEs.

Thus, the Korean government laid the foundation for two government-sponsored public sources of VC funds: the SME Parent Fund and the Growth Ladder Fund. ${ }^{12}$ The former finances capital by issuing government-guaranteed bonds, and the latter was established by government-run banks. If private $\mathrm{VC}$ firms raise money from these public funds, they should be able to raise more capital beyond just the public funds' investments. In short, the government plays a significant role in providing capital for SMEs and startups in Korea. A governmental fund investing in a private VC firm provides an excellent signal, allowing the firm to attract more private capital. ${ }^{13}$ Figure 3 explains the governmental financing process in the SME and startup ecosystem for Korean institutions. Figure 3 also shows that the system for financing SMEs via government finances in Korea is complex. This complexity arises because many related government-affiliated agencies play separate roles in guarantees, loans, and investments. In addition, this financing takes the form of a firm making an indirect loan through a bank rather than directly obtaining funds from a government agency.

SMEs and startups do not necessarily need help from VC firms to be listed on the KOSDAQ or the KONEX. Before listing, firms can also obtain funds from investment banks (or securities companies), commercial banks, pension funds, other corporations, or consortiums of these institutions. However, raising capital from VC firms provides a good signal to the market about a given SME or startup. Thus, founders' and VC firms' financial incentives are aligned such that a VC firm can accelerate a company's growth, ultimately leading to an IPO. The proportion of VC investments in IPO firms is increasing in Korea (see Table 1). 


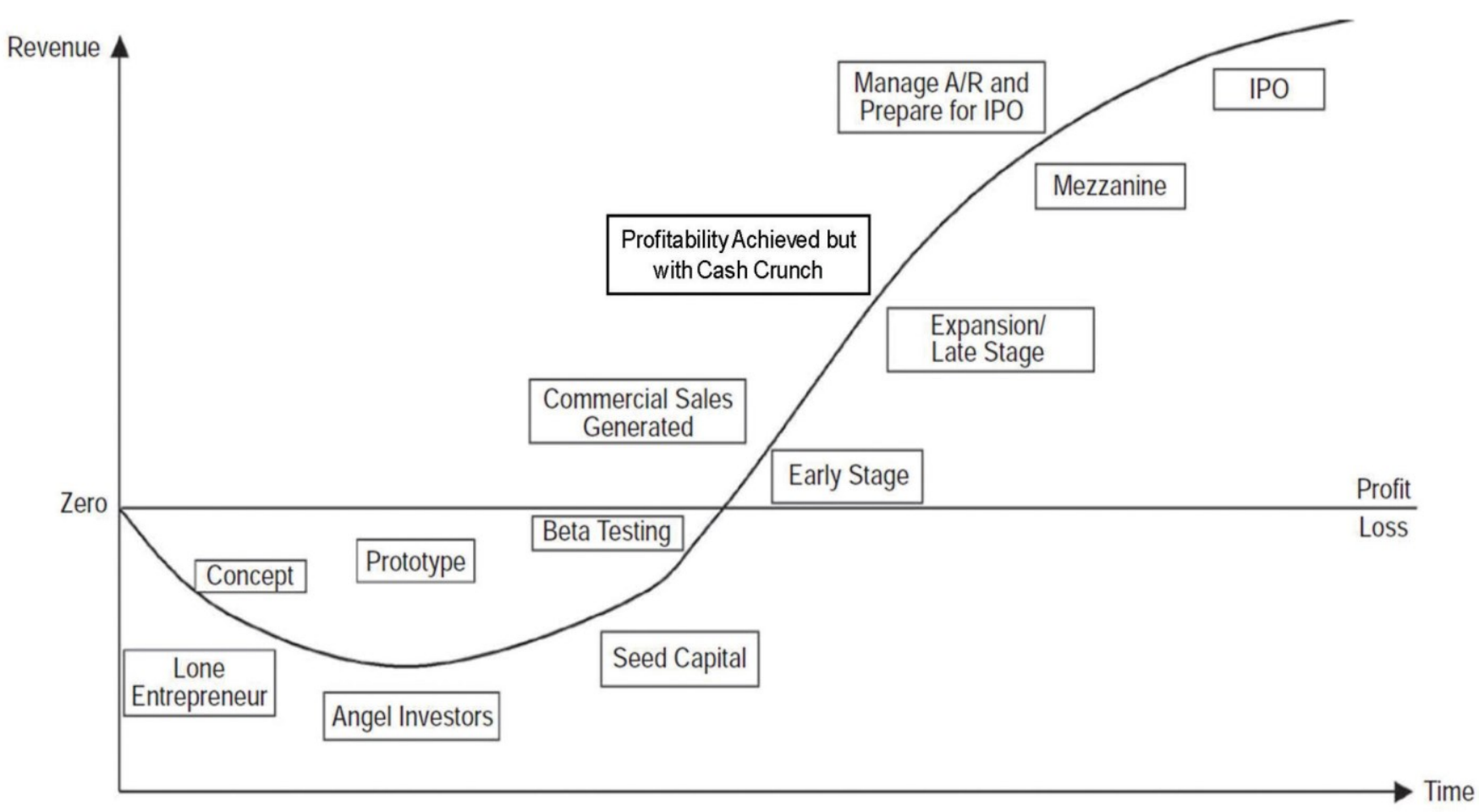

Panel A: Life cycle and staged capital of a startup company

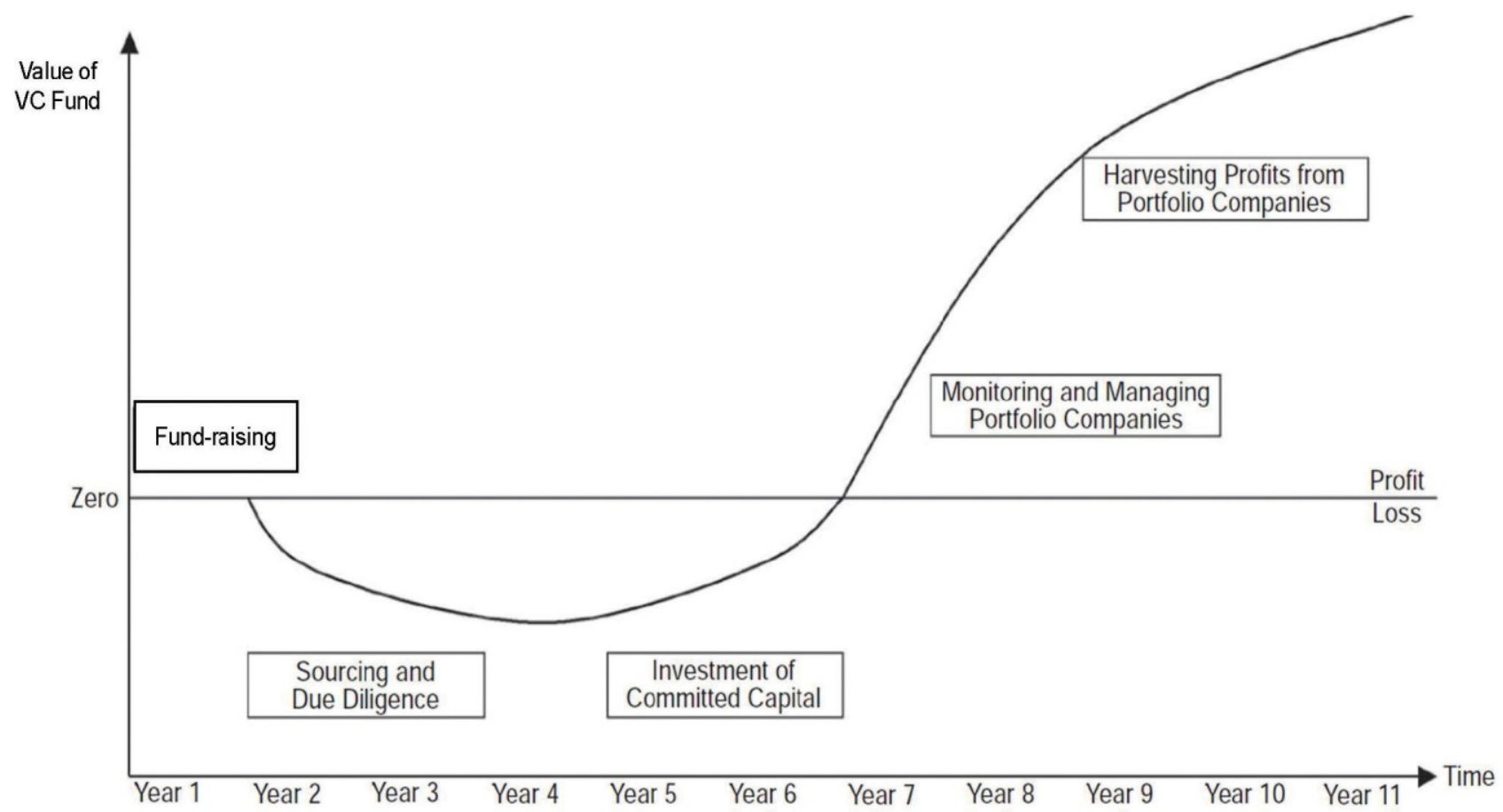

Panel B: Life cycle of a VC fund

Figure 2: Life cycles of a startup company and a VC fund, Source: Anson (2006) 


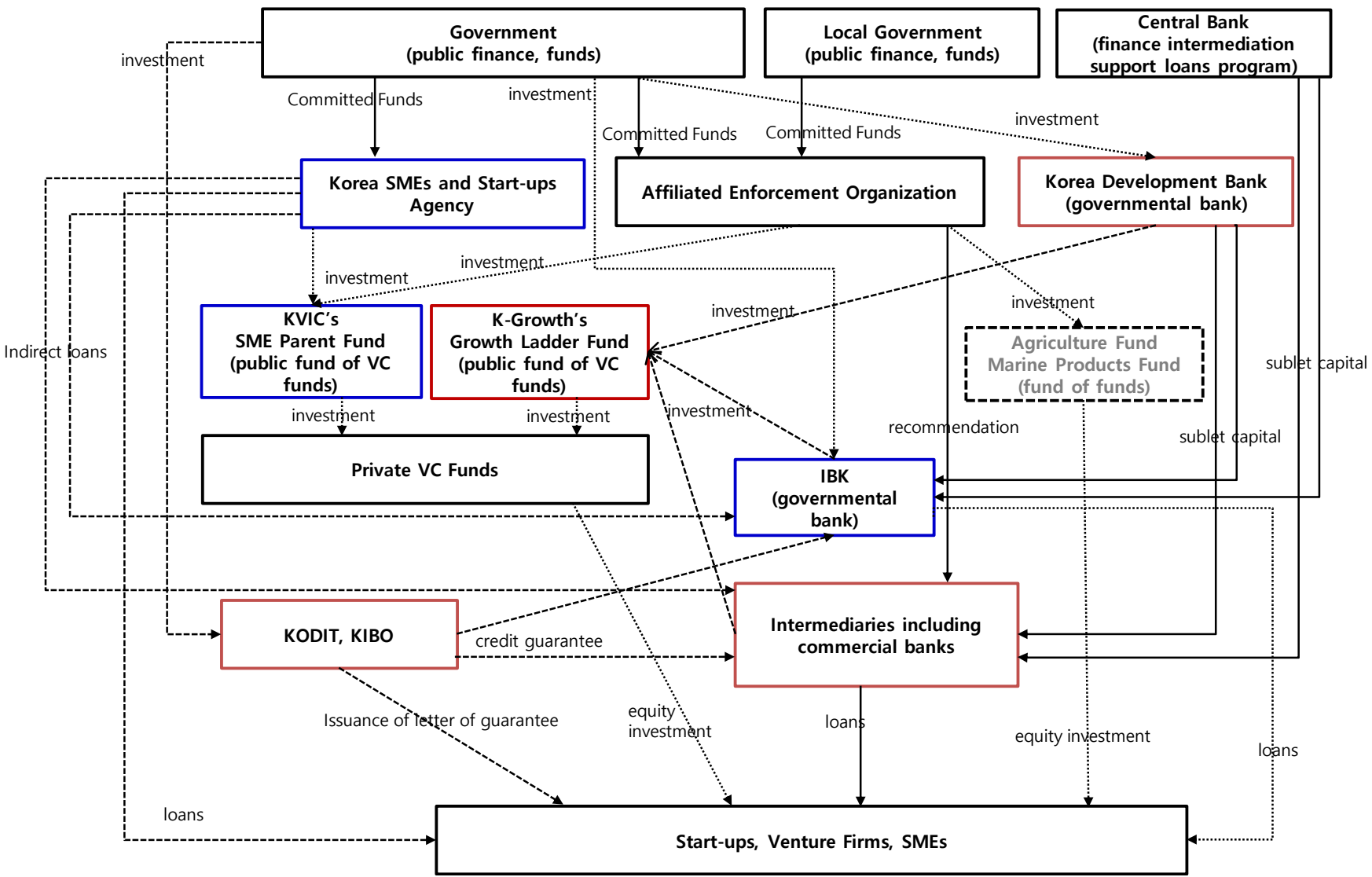

Figure 3: Government-sponsored capital provision system for SMEs in Korea. Note: In this figure, the Agricultural Fund and the Marine Products Fund are public government-sponsored funds of funds to foster venture startups in the agriculture and marine fishery sectors, respectively (Source: Korea Institute of Finance). This figure is based on the 2011 KIF working paper, "SME policy financing support system evaluation and improvement plan," by Lee, K. and Jo, Y. (in Korean)

Table 1: KOSDAQ and VC-backed IPOs in Korea

\begin{tabular}{|l|c|c|c|c|c|c|}
\hline & $\mathbf{2 0 1 4}$ & $\mathbf{2 0 1 5}$ & $\mathbf{2 0 1 6}$ & $\mathbf{2 0 1 7}$ & $\mathbf{2 0 1 8}$ & $\mathbf{2 0 1 9}$ \\
\hline Number of IPOs & 67 & 109 & 70 & 78 & 90 & 97 \\
\hline $\begin{array}{l}\text { Number of VC- } \\
\text { backed IPOs }\end{array}$ & 33 & 60 & 36 & 40 & 47 & 53 \\
\hline$\%$ VC-backed IPOs & $49.3 \%$ & $55 \%$ & $51.4 \%$ & $51.2 \%$ & $52.2 \%$ & $54.6 \%$ \\
\hline
\end{tabular}

Source: Korean Venture Capital Association (KVCA)

\section{Public Capital Markets for SMEs and Startups in Korea}

This section provides a closer look at the KOSDAQ, the KONEX, and P-CBOs, which are central to Korea's economic policy for SMEs.

\subsection{Stock Market Listing Requirements}

The requirements for listing on the stock market are rather stringent, and quantitative measures, such as firm size, aggregate sales volume, and profit, are very important for listing determinations. McKaskill (2009) finds that typical listing conditions are a sales volume above $\$ 20$ million, profits above $\$ 2$ million, an expectation of continued growth, sufficient internal cash holdings, and a total firm size above $\$ 100$ million. For example, a firm may need to meet the following criteria: more than three years of operation, more than $\$ 100$ million in sales volume, more than $\$ 6$ million in net profits, and more than $\$ 30$ million in equity.

Allowing all firms to freely list on the stock exchange is not ideal because investor protections would be highly unlikely to function well owing to information asymmetry. In a stock exchange, institutional investors; various funds, such as 
pension funds, mutual funds, and hedge funds; and individual investors can all trade freely. Hence, strong investor protection measures, such as listing or maintenance requirements, are needed. Firms that do not meet these requirements cannot be listed or are removed from the exchange. A stock exchange may be involved in a lawsuit or required to meet certain legal responsibilities if economic crimes or investor protection failures occur. Thus, stock exchanges tend to set strict listing and maintenance requirements.

However, in general, it is difficult for SMEs and startups to meet such strict listing and maintenance requirements, especially in the case of the KOSPI. SMEs and startups tend to list on the KOSDAQ because it is difficult for them to meet the requirements for listing on the KOSPI. Additionally, the KONEX has significantly fewer listing requirements than the KOSDAQ has. In many cases, listing on the KOSDAQ is a better option for SMEs. In a sense, the KONEX can be seen as a minor-league exchange; many small enterprises and startups tend to list on the KONEX first owing to its fewer requirements and then list again on the KOSDAQ or KOSPI after growing large enough to do so. This listing convention is consistent with the purpose of the KONEX.

McKaskill (2009) presents typical requirements for listing on a general stock market, as shown in Table 2. If stock exchanges set high bars for listing, SMEs and startups cannot benefit from the public capital market. As a result, new stock exchange boards with lower listing and maintenance requirements, such as the KOSDAQ, have emerged worldwide. Because the KOSDAQ has weaker listing and maintenance requirements, investors face relatively more breach of trust, embezzlement, and stock price manipulation cases, leading to weak investor protections. Thus, the government should strike a balance between policies to nurture SMEs and startups and policies to protect investors.

\subsection{KOSDAQ}

As previously mentioned, every political regime in Korea has set a policy for nurturing SMEs and startups as one of the major governmental policies. In 1987, the KSDA opened an over-the-counter capital market specifically for SMEs and startups to more easily facilitate the raising of capital. Since then, the number of corporations registered in this market increased, reaching over 300 in 1994. Many firms issued stocks and bonds in this market; the annual volume of the traded stock increased from $\$ 100$ million in 1992 to $\$ 332$ million in 1994 , and the total amount of issued stocks and bonds also increased from \$4.5 million in 1987 to $\$ 669.9$ million in $1994 .{ }^{14}$ However, the KOSDAQ is more advanced and better organized than this over-the-counter capital market was.

Table 2: Ordinary stock market listing requirements

\begin{tabular}{|c|c|}
\hline Attribute & Requirement for long-term attractive public listings \\
\hline Revenue & Over $\$ 20$ million (over $\$ 100$ million for the most successful). \\
\hline Net profit & $\begin{array}{l}\text { Profitable for three years, with a minimum profit of } \$ 2 \text { million in the year prior to listing. } \\
\text { Projected growth in profits over the next few years. }\end{array}$ \\
\hline Scope & National or international markets. \\
\hline Portfolio & Range of products, with some in different markets. \\
\hline Potential & Major national or global market leadership. \\
\hline Management & Majority with public corporation experience and some with experience in larger corporations. \\
\hline Board & Significant industry and public corporation experience. \\
\hline CEO & Able to deal with market analysts, institutions, and shareholders. \\
\hline R\&D & Products in various stages of development to ensure continued market leadership. \\
\hline Cash & Sufficient funds to achieve forecasts without raising further capital. \\
\hline Funds use & $\begin{array}{l}\text { Funds raised to be used for market development, innovation, overseas expansion, acquisitions, working } \\
\text { capital, or repayment of debts. }\end{array}$ \\
\hline Advantage & Clear competitive advantage based on strong intellectual property or a proven innovative business model. \\
\hline $\begin{array}{l}\text { Public } \\
\text { awareness }\end{array}$ & Products and their benefits are easily understood by the public. \\
\hline Support & $\begin{array}{l}\text { Value and number of listed shares are large enough in institutional and public ownership to encourage } \\
\text { market analysts to track the stock. } \\
\text { Generally, market capitalization should be at least } \$ 100 \text { million. }\end{array}$ \\
\hline
\end{tabular}

Source: McKaskill (2009) 
The KOSDAQ was launched in 1996. The previous overthe-counter market was a secondary capital market and was considered a minor-league market; it was a preliminary market before listing on the KOSPI. However, the KOSDAQ should not be regarded as ranking below the KOSPI. In the US, the NASDAQ is not ranked below the NYSE even though it was established later and larger companies are usually listed on the NYSE. As is well known, IT giants, such as Apple, Intel, Microsoft, Facebook, and Amazon, are listed on the NASDAQ. Thus, the NYSE and the NASDAQ are competitors. Unlike in the US, where both the NYSE and the NASDAQ are privately held, in Korea, the KRX, which is strongly influenced by the government, has monopolistic power over running securities exchanges.

The KOSDAQ was not established with the intention of listing relatively immature and less qualified firms that cannot meet the requirements for listing on the KOSPI. When the KOSDAQ first opened in 1996, the growth in technology, particularly internet technologies, resulted in many new technology firms entering the market. In the new business environment related to these new technologies, conventional accounting practices that emphasize firm size and the quality of financial statements are not entirely suitable for the aforementioned new firms. Consequently, the need for a new capital market to help new technology firms raise capital based on assessments of their technological potential increased, leading the government to establish the KOSDAQ.

There are many examples of newly established stock markets for SMEs that are separate from the standard major stock markets. The JASDAQ and MOTHERS in Japan, the CHASDAQ in China, AIM in the UK, the TSX in Canada, and Euronext Growth in Europe are representative examples. The KOSDAQ has the largest market capitalization among the alternative SME markets listed in Annual Statistics Guide 2019 by the World Exchange Federation. However, the KOSDAQ has many negative characteristics, such as rather high stock price volatility, frequent malpractice and embezzlement among listed firms, and even stock price manipulations. The KOSDAQ market index was 1,000 in 1996 but only 669.83 at the end of 2019. Because of the KOSDAQ's bad reputation, many successful firms listed on the KOSDAQ tend to move to the KOSPI once they grow enough. Representative examples include NHN (Naver), NC Soft, Celltrion, and Kakao. These moves create further problems for the KOSDAQ.

Given these circumstances, the KOSDAQ is regarded as a preparatory or middle-stage market for firms that aim to eventually be listed on the KOSPI. This perspective reflects a serious misunderstanding of the KOSDAQ and is not consistent with its initial purpose of cultivating small hightech firms. Although the KOSDAQ still faces many substantive issues, as many as 1,000 firms, on average, have been listed on the KOSDAQ since 2000. ${ }^{15}$ The KOSDAQ has significantly contributed to these firms' growth and ability to raise capital. Although it is difficult for new SMEs and startups to list on the KOSDAQ, non-listed firms that have grown successfully tend to be listed on the KOSDAQ. Currently, the standard practice is for new SMEs and startups to first list on the KONEX and then move to the KOSDAQ when they become ready for the next stage. Although some SMEs and startups do not want to list on these stock exchanges owing to their relatively high listing costs and other restrictions, listing offers various advantages, as follows.

- Divestment (exit) opportunities for founders and VC investors.

- Stock market listing premiums for founders and VC investors.

- Opportunity to improve and establish an objective firm value.

- Increased reputation or brand value for the firm.

- Greater probability of issuing bonds through increased credit ratings.

- Easier access to seasoned equity offerings.

Without the KOSDAQ, most of its 1,000 listed firms would not have had the opportunity to be listed. Despite the negative impressions of the KOSDAQ, many IT, biotech, and gaming firms, such as NHN, NC Soft, Celltrion, Kakao, and Seoul Semi-Conductor, have used this exchange to achieve explosive growth. Recently, many biotech firms, such as Sillajen, Meditox, Viromed, Tissuegene, Komipharm, and some affiliates of Celltrion, have emerged on the KOSDAQ. Listing on the KOSDAQ may be ideal for successful VC investments, underscoring the KOSDAQ's important role as a public capital market for SMEs and startups. Moreover, although the KOSDAQ index is still stagnant, its trading activity and market liquidity are growing (http://investing.com).

In Korea, individual investors can trade stocks through securities companies that are authorized by the Investment Brokerage Business under the Capital Market and Financial Investment Act through the Financial Services Commission, the primary governmental authority in the financial sector. As online trading has grown, stock trading on personal computers or mobile devices through home trading systems (HTSs) has become widespread. All securities can be traded simultaneously on one HTS screen. Different HTSs use the same trading method, that is, real-time double auctions. Individual investors often may not notice whether the stocks they are trading are listed on the KOSPI or the KOSDAQ, and recognizing this distinction provides no discernable benefit.

Table 3 shows the listing requirements for both general companies and SMEs and startups for the KOSPI and the KOSDAQ. Compared to the KOSPI, the KOSDAQ has fairly weak listing requirements, and the listing requirements for SMEs and startups are even weaker. 
Table 3: Listing requirements for the KOSPI and the KOSDAQ

\begin{tabular}{|c|c|c|}
\hline & \multicolumn{2}{|l|}{ KOSPI } \\
\hline & General Company & Holding Company \\
\hline $\begin{array}{l}\text { Business } \\
\text { Size }\end{array}$ & At least KRW 30 billion & At least KRW 30 billion \\
\hline $\begin{array}{l}\text { Years of Operation } \\
\text { since Incorporation }\end{array}$ & At least three years & At least three years \\
\hline \multirow[t]{3}{*}{$\begin{array}{l}\text { Financial } \\
\text { Performance }\end{array}$} & $\begin{array}{l}\text { ※ Sales: Above KRW } 100 \text { billion for the latest } \\
\text { fiscal year and above KRW } 70 \text { billion on } \\
\text { average for the three most recent fiscal years } \\
\text { ※ The following requirements must be met: } \\
\text { (1) Profit: Above KRW } 3 \text { billion in the latest fiscal } \\
\text { year and above KRW } 6 \text { billion in total over the } \\
\text { three most recent fiscal years } \\
\text { (2) ROE: Above } 5 \% \text { in the latest fiscal year and } \\
\text { above } 10 \% \text { in total over the three most recent } \\
\text { fiscal years } \\
\text { (3) For large companies (companies with equity } \\
\text { capital over KRW } 100 \text { billion): ROE above } 3 \% \\
\text { or profits above } 5 \text { billion and positive operating } \\
\text { cash flow }\end{array}$ & $\begin{array}{l}\text { ※ Sales: Above KRW } 100 \text { billion for the latest } \\
\text { fiscal year and above KRW } 70 \text { billion on } \\
\text { average for the three most recent fiscal years } \\
\text { ※ The following requirements must be met: } \\
\text { (1) Profit: Above KRW } 3 \text { billion in the latest fiscal } \\
\text { year and above KRW } 6 \text { billion in total over the } \\
\text { three most recent fiscal years } \\
\text { (2) ROE: Above } 5 \% \text { in the latest fiscal year and } \\
\text { above } 10 \% \text { in total over the three most recent } \\
\text { fiscal years } \\
\text { (3) For large companies (companies with equity } \\
\text { capital over KRW } 100 \text { billion): ROE above } 3 \% \\
\text { or profit above } 5 \text { billion and positive operating } \\
\text { cash flow }\end{array}$ \\
\hline & \multicolumn{2}{|l|}{ KOSDAQ } \\
\hline & General Company & Venture Company \\
\hline $\begin{array}{l}\text { Business } \\
\text { Size }\end{array}$ & $\begin{array}{l}\text { Equity capital of at least KRW } 3 \text { billion or base } \\
\text { market capitalization of at least KRW } 9 \text { billion }\end{array}$ & $\begin{array}{l}\text { Equity capital of at least KRW } 1.5 \text { billion or base } \\
\text { market capitalization of at least KRW } 9 \text { billion }\end{array}$ \\
\hline $\begin{array}{l}\text { Years in Operation } \\
\text { since Incorporation }\end{array}$ & At least three years & No requirement. \\
\hline $\begin{array}{l}\text { Financial } \\
\text { Performance }\end{array}$ & $\begin{array}{l}\text { ※ The following requirements must be met: } \\
\text { (1) Net income: Above KRW } 2 \text { billion } \\
\text { (2) ROE: Above } 10 \% \\
\text { (3) Sales amount: Above KRW } 10 \text { billion, with } \\
\text { a total market capitalization above KRW } 30 \\
\text { billion } \\
\text { (4) Sales growth: Above } 20 \% \text {, with sales amount } \\
\text { above KRW } 5 \text { billion }\end{array}$ & $\begin{array}{l}\text { ※ The following requirements must be met: } \\
\text { (1) Net income: Above KRW } 1 \text { billion } \\
\text { (2) ROE: Above } 5 \% \\
\text { (3) Sales amount: Above KRW } 5 \text { billion, with a } \\
\text { total market capitalization above KRW } 30 \\
\text { billion } \\
\text { (4) Sales growth: Above } 20 \% \text {, with sales amount } \\
\text { above KRW } 5 \text { billion }\end{array}$ \\
\hline
\end{tabular}

Source: KRX home page (http://www.krX.co.kr)

Firms can be certified as SMEs or startups by the $\mathrm{KIBO}$, the KOSME, and the KVCA. For listing on the KOSDAQ, firm age does not matter, the required amount of equity is about one-twentieth of the KOSPI equity requirement, and the required sales volume is about onetenth of the KOSPI requirement. A firm can list on the KOSDAQ even if it does not meet the sales volume requirement as long as it meets the requirement for sales volume growth. In contrast with the KOSPI, the KOSDAQ emphasizes technology and the possibility of future growth; current firm size, firm age, and profitability are not critical.

We note that the listing requirements are weaker for technology growth firms as well as for ordinary SMEs and startups; firms can be selected as technology growth firms if they are evaluated by technology valuation companies as having technology that is valued above the BBB grade. Technology growth firms can list on the KOSDAQ if they are free of any capital impairment and their equity is worth more than $\$ 1$ million. 
As of January 2018, the Korean government announced a new policy to facilitate the KOSDAQ's development. ${ }^{16}$ Like previous political regimes, the current regime emphasizes the importance of SMEs. For this policy to be successful, more SMEs should benefit from listing on the KOSDAQ, and, furthermore, the KOSDAQ should become more active through greater capital flows or investments. Among the government's policy announcements, the most notable is the plan to relax the KOSDAQ's listing requirements. In particular, this plan includes the so-called Tesla condition, by which SMEs and startups that currently do not generate positive earnings can still list on the KOSDAQ. Additionally, various financial benefits and tax support can induce greater participation by individual investors, pension funds, KOSDAQ venture funds, and so on. Plans are also in place to bolster regulations that can enhance the KOSDAQ's transparency and fairness.

As of March 2018, a total of 1,268 firms are listed on the KOSDAQ, and a total of 777 firms are listed on the KOSPI. Statistics indicate that about 300-400 firms were listed on the KOSDAQ at the end of 1990 . The total market size of the KOSDAQ was initially 8.4 billion KRW in 1996, but it has reached around 241 trillion KRW as of the end of 2019. Thus, the KOSDAQ has grown significantly, both quantitatively and qualitatively, over the last 23 years. The number of listed firms is above 1,000 on average and has significantly increased since 2015 . The total market size increased significantly in 2017. Table 4 provides a list of firms that moved from the KOSDAQ to the KOSPI. ${ }^{17}$

\subsection{KONEX}

The KONEX was first established in 2013. Its purpose is to help small enterprises and startups raise capital in the market and to support $\mathrm{VC}$ firms in recovering their investments in the medium term. Thus, the KONEX exists to establish a virtuous cycle from launching a new business to firm growth and investment recovery or reinvestment, which induces more investments in small enterprises and startups, and it is explicitly a market for small enterprises and startups.

Ironically, the necessity of establishing another stock exchange board for SMEs and startups in addition to the KOSDAQ stems from the KOSDAQ itself. Many negative incidents, including breaches of trust, embezzlements, and stock price manipulations, have occurred in the KOSDAQ, and the need for stronger investor protections has grown. In a sense, investor protections can conflict with policies supporting SMEs and startups in raising capital. However, the KOSDAQ has taken a stronger stance on investor protections, meaning that larger and more mature SMEs and startups that have been active in the market relatively longer tend to list on the KOSDAQ. Thus, the KOSDAQ is a relatively secure stock exchange for larger and more experienced firms rather than an exchange for ordinary SMEs or startups.
Table 4: Listed companies that switched from the KOSDAQ to the KOSPI by year

\begin{tabular}{|l|l|c|}
\hline Year & \multicolumn{1}{|c|}{ Company Name } & \# Firms \\
\hline 1999 & $\begin{array}{l}\text { DCM, Hyundai Heavy Industries, Kira } \\
\text { Telecom, Mirae ING Co, Daewon } \\
\text { Pharm }\end{array}$ & 5 \\
\hline 2000 & $\begin{array}{l}\text { TLC Leisure, Hansae Yes24, Korea } \\
\text { Refractories }\end{array}$ & 3 \\
\hline 2001 & Coway, Feelux & 2 \\
\hline 2002 & $\begin{array}{l}\text { Kolmar Holding, Wooshin System, } \\
\text { Shinsegae Construction, Kyobo } \\
\text { Securities, } \\
\text { Sejong Industrial, S\&TC, Maniker }\end{array}$ & 7 \\
\hline 2003 & $\begin{array}{l}\text { Taekyung Chem, NC Soft, SBS, } \\
\text { Kangwon Land, Isupetasys, IBK }\end{array}$ & 6 \\
\hline 2004 & KTF, Infac, Sangsin Brake & 3 \\
\hline 2005 & Samho Dev & 1 \\
\hline 2006 & $\begin{array}{l}\text { Shinsegae I\&C, Woojin Plaimm, } \\
\text { Cosmax }\end{array}$ & 3 \\
\hline 2007 & United Pharm & 1 \\
\hline 2008 & $\begin{array}{l}\text { Asiana Airline, LG Uplus, Bookook } \\
\text { Steel, NHN Corp. }\end{array}$ & 4 \\
\hline 2009 & Kiwoom, Hwang-Kum Steel & 2 \\
\hline 2010 & $\begin{array}{l}\text { Shinsegae Food, Muhak, Tongyang } \\
\text { Network }\end{array}$ & 3 \\
\hline 2011 & Kolon Inet, Able C\&C, Hana Tour & 3 \\
\hline 2016 & $\begin{array}{l}\text { Korea Real Estate Investment \& } \\
\text { Trust Co., Ltd., Dongsuh }\end{array}$ & 2 \\
\hline 2017 & Kakao Corp & 1 \\
\hline 2018 & Celltrion Inc. & \\
\hline
\end{tabular}

For instance, the average sales volume of firms listed on KOSDAQ is about $\$ 100$ million, which is an impossible target for most SMEs and startups to achieve.

As a result, despite some criticism that the KOSDAQ's and KONEX's roles overlap to some extent, the financial authority decided to launch a new stock exchange board by establishing the KONEX, which has much weaker listing requirements. One of the main reasons for establishing this new stock exchange board was to create a way for VC firms to recover their investments; before the KONEX was established, VC firms had no effective way of doing so. The only channel for recovering investment on the KOSDAQ was making an IPO, but the exchange's strict listing requirements prevented easy IPOs. Thus, the KONEX provides a means of recovering investments in SMEs and startups; when it is difficult for a firm to go public on the KOSDAQ, its founder and VC firms can list the firm on 
the KONEX and potentially sell it to other investors later. In the case of a sell-off, the buying counterparty is usually a corporation (strategic investors), another VC firm, or a PE fund. Thus, the KONEX can promote secondary trades among VC or PE firms. Notably, stocks listed on the KONEX tend to carry higher risk, mainly because of the weaker listing requirements; hence, investor protections are weaker. Instead, individual investors are prevented from investing in the KONEX at all. Only institutional investors, pension funds, professional investors (i.e., individual qualified investors), and corporations that are approved for trading by the financial authority can invest in the KONEX. ${ }^{18}$

Before the KONEX was established, the Freeboard was a well-organized over-the-counter capital market. However, trading on the Freeboard was infrequent, and it therefore lost its functionality as a capital market. The financial authority ultimately discontinued the Freeboard by establishing the KONEX and the newly opened K-OTC board to enable easier and more transparent trades. OTCBB and PinkSheet in the US are benchmarks for the K-OTC board.

We next compare the listing requirements of the KONEX to those of the KOSPI and the KOSDAQ. First, the KONEX requires firms to have either $\$ 5$ million in equity, $\$ 1$ million in annual sales, or $\$ 0.3$ million in earnings for listing. Second, firms are exempt from submitting a preliminary prospectus if they meet certain conditions. ${ }^{19}$ Third, in the private placement of stocks, the KONEX does not require the lockup agreements that are required by the KOSPI and the KOSDAQ. Fourth, the KONEX imposes fewer restrictions on public announcements; firms listed on the KONEX can announce their business reports only once a year, whereas firms listed on the KOSPI or the KOSDAQ must make quarterly public announcements. Fifth, whereas firms listed on the KOSPI and the KOSDAQ must make timely disclosures of important incidents, firms listed on the KONEX do not face this requirement. Sixth, firms listed on the KOSPI or the KOSDAQ must follow Korea-International Financial Reporting Standards for accounting practices, whereas KONEX firms are not required to do so. Lastly, firms listed on the KONEX for over a year are exempt from many restrictions when they move to the KOSDAQ.

We also consider changes in the KONEX over time. In general, the overall total market capitalization, the number of listed firms, daily trade volumes, and so on tend to steadily increase. The total market capitalization of the KONEX has increased from 469 billion KRW to 5,325 billion KRW (11.35 times), and the number of listed firms has increased from 45 to 151 in 2019 (3.36 times), indicating that the KONEX has steadily developed both quantitatively and qualitatively over time.

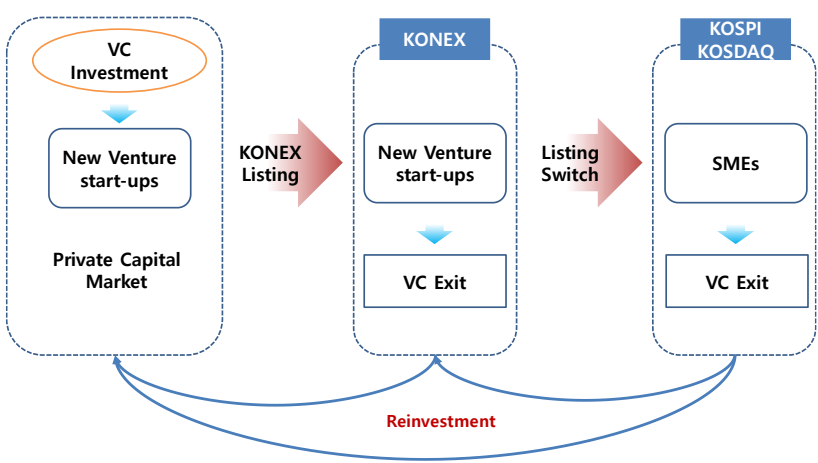

Figure 4: The KONEX in the Korean venture and VC ecosystem

The stock market is as important as a primary market as it is as a secondary market. The KONEX opened in 2013. KRX (2018) shows that 97 firms have raised capital 223 times, for a total of about $\$ 510$ million as of the end of 2017. This capital has primarily been raised through SEOs by PE funds and the issuance of convertible debt. Additionally, the amount of capital raised has increased over time. Importantly, the KONEX is a preliminary market before listing on the KOSDAQ or the KOSPI. By the end of 2017, 32 KONEX firms had moved to the KOSDAQ through M\&As by SPACs that were listed on the KOSDAQ. ${ }^{20}$ M\&As by SPACs serve as a type of backdoor listing (Datar et al., 2012).

Figure 4 shows that the private venture capital market and the public KONEX and KOSDAQ markets organically play essential roles in the Korean venture ecosystem.

\subsection{P-CBO Market}

The bond market occupies a significant portion of the Korean financial market. The trading volume of government bonds, public debt, bank debentures, and corporate bonds amounts to $\$ 7,000$ billion annually, and the balance of these bonds is about $\$ 1,830$ billion as of the end of 2017. Additionally, the balance of corporate bonds other than bank debentures and financial bonds is about $\$ 235$ billion. Tables 5 and 6 include P-CBOs that are issued by SMEs. Thus, government bonds and public debt comprise a significant portion of the bond market. In the Korean bond market, even the most secure corporate bonds, which are issued by large enterprises, are not easily digested by the private market, meaning that government-run banks, such as the KDB, play a major role in underwriting corporate bonds from large enterprises. Thus, SMEs and startups cannot issue corporate bonds with their own credit in this market. 
Table 5: Trading values in Korean bond markets

\begin{tabular}{|l|c|c|c|c|c|c|c|c|c|c|}
\hline Issuer & $\mathbf{2 0 1 0}$ & $\mathbf{2 0 1 1}$ & $\mathbf{2 0 1 2}$ & $\mathbf{2 0 1 3}$ & $\mathbf{2 0 1 4}$ & $\mathbf{2 0 1 5}$ & $\mathbf{2 0 1 6}$ & $\mathbf{2 0 1 7}$ & $\mathbf{2 0 1 8}$ & $\mathbf{2 0 1 9}$ \\
\hline Government & 3,777 & 4,013 & 4,695 & 4,953 & 4,279 & 4,654 & 5,741 & 4,634 & 4,667 & 4,479 \\
\hline Municipal & 25 & 16 & 20 & 19 & 18 & 21 & 16 & 14 & 13 & 16 \\
\hline National Banks & 229 & 245 & 373 & 340 & 308 & 295 & 271 & 257 & 220 & 220 \\
\hline $\begin{array}{l}\text { Central Bank } \\
\text { (BOK) }\end{array}$ & 1,414 & 1,612 & 1,491 & 1,403 & 1,223 & 1,271 & 1,138 & 1,132 & 1,201 & 952 \\
\hline Commercial Banks & 555 & 485 & 394 & 376 & 367 & 413 & 437 & 477 & 523 & 576 \\
\hline $\begin{array}{l}\text { Other Financial } \\
\text { Institutions }\end{array}$ & 80 & 97 & 121 & 162 & 213 & 179 & 175 & 215 & 277 & 358 \\
\hline Corporations & 143 & 182 & 195 & 178 & 162 & 123 & 120 & 128 & 144 & 173 \\
\hline ABS & 18 & 28 & 32 & 37 & 35 & 31 & 35 & 44 & 74 & 120 \\
\hline Total & 6,242 & 6,679 & 7,321 & 7,469 & 6,604 & 6,986 & 7,933 & 6,900 & 7,119 & 6,893 \\
\hline
\end{tabular}

Source: Korea Financial Investment Association, http://freesis.kofia.or.kr. Note: The units are trillion KRW.

Table 6: Issuances and outstanding values in Korean bond markets

\begin{tabular}{|l|c|c|}
\hline Issuer & $\begin{array}{c}\text { Issuance } \\
\text { Value in 2019 }\end{array}$ & $\begin{array}{c}\text { Outstanding Value } \\
\text { at the end of 2019 }\end{array}$ \\
\hline Government & 165,766 & 687,843 \\
\hline $\begin{array}{l}\text { Local } \\
\text { Governments }\end{array}$ & 4,550 & 21,304 \\
\hline National Banks & 63,949 & 332,203 \\
\hline $\begin{array}{l}\text { Central Bank } \\
\text { (BOK) }\end{array}$ & 142,070 & 164,060 \\
\hline $\begin{array}{l}\text { Commercial } \\
\text { Banks }\end{array}$ & 134,910 & 308,635 \\
\hline $\begin{array}{l}\text { Other Financial } \\
\text { Institutions }\end{array}$ & 58,000 & 161,615 \\
\hline Corporations & 91,677 & 290,206 \\
\hline ABS & 25,964 & 49,587 \\
\hline Total & 685,886 & $2,015,453$ \\
\hline
\end{tabular}

Source: Korea Financial Investment Association, http://freesis.kofia. or.kr. Note: The units are billion KRW.

P-CBOs were first introduced in 2000 by the Korean government for the purpose of helping SMEs and startups raise capital, as these firms have difficulty issuing corporate bonds owing to their low credit quality. ${ }^{21}$ In other words, this system was developed to increase SMEs' and startups' access to the capital market. Figure 5 shows the issuance structure of a P-CBO. P-CBOs are a special form of ABSs.
First, corporate bonds issued by SMEs or startups are underwritten by securities firms. Then, those bonds are sold to a special purpose company (SPC) that serves as a transfer or pass-through conduit for securitization. The SPC issues a CBO based on a collateralized asset pool that it holds. The issued CBOs are guaranteed by the KODIT or the KIBO, which are governmental financial institutions that serve as credit enhancers. Securitized P-CBOs help to diversify credit risk through a pool of corporate bonds from many different SMEs and startups. In early 2000, the Korean government started promoting $\mathrm{P}-\mathrm{CBO}$, and the KODIT and the KIBO have been involved from the beginning. As a result, SMEs and startups can raise capital at full scale through the bond markets. When P-CBOs were introduced, Korea was gradually recovering from the 1997 financial crisis. However, a credit crunch initiated by credit card corporate bond defaults occurred in 2003, sparking another financial crisis; most credit card companies provided card loans with indiscretion to benefit from high-interest rates. The source of funds for these card loans was card bonds issued by credit card companies. As many card loans became insolvent, the largest credit card company, LG Card, ultimately went bankrupt, immediately sparking an overall credit crisis.

As this economy-wide credit crunch negatively affected SMEs and startups, P-CBOs were unable to diversify credit risk. P-CBOs can diversify individual credit risk, but the overall economy-wide credit risk stays the same. Many PCBOs went bankrupt and were repaid by government-run banks. In 2004, the payment amount through subrogation reached over $\$ 3$ billion, accompanied by an earnings loss of $\$ 2$ billion. Even government-run banks faced default risk. 


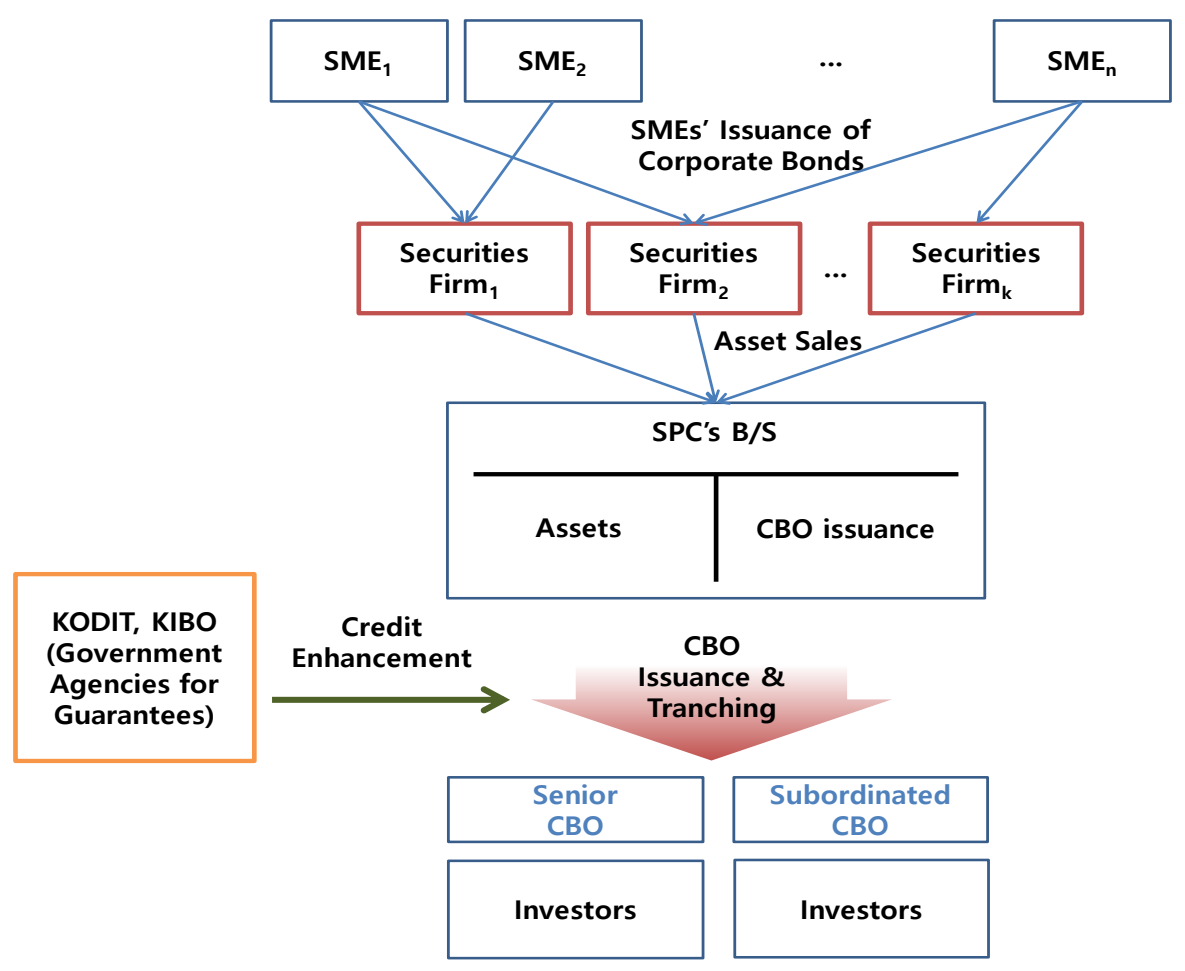

Figure 5: Issuance structure of P-CBOs in the Korean SME financial market

As of 2018, the Korean financial market still has a negative impression of P-CBOs because people remember that government-run banks, which guarantee P-CBOs, almost defaulted owing to the mass defaults of P-CBOs. However, the crisis did not occur because of problems with SMEs' credit. Rather, it was initiated by a systematic credit crunch that originated from the defaults of large credit card companies, that is, the so-called credit card issuers' bond crisis.

P-CBOs may be the only way for SMEs and startups to raise capital by issuing corporate bonds. Unfortunately, many P-CBOs became poor or insolvent in 2004 and 2005, mainly because the government pushed their use too quickly. The two major governmental guarantee agencies, the KODIT and KIBO, became financially distressed as a result. ${ }^{22}$ Since then, the introduction of P-CBOs has been regarded as a failure or as an example of bad policy. The system's purpose and goal were desirable, but there were problems in the selection and monitoring of bond issuers.

Although the amount of P-CBOs issued greatly decreased during the 2004 crisis, P-CBOs were still used as a tool in the 2008 global financial crisis to deal with the construction company crisis caused by a real estate market downturn. They served as a way for SMEs to issue corporate bonds and as an instrument for boosting the bond market. Clearly, the Korean government has led all of these activities, and the KODIT, the KIBO, and the KOSME have taken the lead in issuing P-CBOs. Finally, the P-CBO system cannot function independently in a private market without governmental intervention.

\section{Concluding Remarks}

In this study, we investigate the capital market for SMEs and startups in Korea. The Korean government has emphasized the importance of cultivating SMEs and startups since 1960, and SME policy has always been an important aspect of government policy. Korea can therefore serve as a helpful reference for other emerging markets. Korea's capital market can be split into the private and public capital markets. In the former market, VC firms are the primary source of capital, whereas, in the latter market, the public securities market provides capital. In the private capital 
market, funds mainly come from the public funds that invest in VC firms, bank loans, and governmental guarantees; hence, firms primarily use public resources. Conversely, in the public capital market, although large enterprises can issue stocks and bonds based on their own credit, SMEs and startups greatly require systematic help based on government policy.

The KOSDAQ and the KONEX are both stock exchanges in which investors can trade the stocks of (mostly) SMEs and startups. Initially, the KOSDAQ was a successful alternative stock exchange for SMEs and startups. However, as investor protections in the KOSDAQ have increased, its role as a stock market for SMEs has receded. As a result, the KONEX was established with much weaker listing requirements, and, currently, the KONEX is explicitly becoming a stock market for SMEs and startups. Thus, the KONEX is expected to significantly contribute to the virtuous cycle of the venture ecosystem by providing a way for $\mathrm{VC}$ firms to recover their investments. It is almost impossible for SMEs and startups to issue corporate bonds based on their own credit. Thus, the Korean government introduced the P-CBO system, which provides many SMEs and startups with the freedom to issue bonds. Although P-CBOs experienced a severe credit crisis in 2004, it remains the only way for SMEs and startups to issue corporate bonds.

Private funds and financial institutions play a major role in the public securities market. The government does not need to step in to support large enterprises raising capital. However, it does need to intervene in the capital market for SMEs and startups because many of them cannot easily access the public securities market. The KONEX and PCBOs provide this access in Korea.

\section{References}

Anson, M.J. (2006). Handbook of Alternative Asset. Hoboken, NJ: John Wiley \& Sons.

Ayyagari, M., Demirguc-Kunt, A., \& Maksimovic, V. (2014). Who creates jobs in developing countries? Small Business Economics, 43, 75-99. https://doi.org/10.1007/s11187-0149549-5

Berger, A. N., \& Schaeck, K. (2011). Small and medium-sized enterprises, bank relationship strength, and the use of venture capital. Journal of Money, Credit and Banking, 43, 461-490. https://doi.org/10.1111/j.1538-4616.2010.00381.x

Berger, A. N., \& Udell, G. F. (1995). Relationship lending and lines of credit in small firm finance. Journal of Business, 68(3), 351381. http://dx.doi.org/10.1086/296668

Berger, A. N., \& Udell, G. F. (1998). The economics of small business finance: The roles of private equity and debt markets in the financial growth cycle. Journal of Banking and Finance, 22, 613-673. https://doi.org/10.1016/S0378-4266(98)00038-7
Berger, A. N., \& Udell, G. F. (2006). A more complete conceptual framework for SME finance. Journal of Banking \& Finance, 30(11), 2945-2966. https://doi.org/10.1016/j. jbankfin.2006.05.008

Brander, J. A., Du, Q., \& Hellmann, T. (2015). The effects of government-sponsored venture capital: International evidence. Review of Finance, 19(2), 571-618. https://doi.org/10.1093/rof/ rfu009

Brewer, E., Genay, H., Jackson, W. E., \& Worthington, P. R. (1996). Performance and access to government guarantees: The case of small business investment companies. Economic Perspectives, Federal Reserve Bank of Chicago, 20, 16-30.

Brown, J. D., \& Earle, J. S. (2017). Finance and growth at the firm level: Evidence from SBA loans. Journal of Finance, 72(3), 1039-1080. https://doi.org/10.1111/jofi.12492

Carbo-Valverde, S., Rodriguez-Fernandez, F., \& Udell, G. F. (2016). Trade credit, the financial crisis, and SME access to finance. Journal of Money, Credit and Banking, 48(1), 113143. https://doi.org/10.1111/jmcb.12292

Clementi, G. L., \& Hopenhayn, H. A. (2006). A theory of financing constraints and firm dynamics. Quarterly Journal of Economics, 121(1), 229-265. https://doi.org/10.1093/qje/121.1.229

Ćorić, B. (2010). Investments and capital market imperfections, identification issues: a survey. Financial Theory and Practice, 34(4), 407-434.

Datar, V., Emm, E., \& Ince, U. (2012). Going public through the back door: A comparative analysis of SPACs and IPOs. Banking \& Finance Review, 4(1), 17-36.

De Carvalho, A. G., \& Pennacchi, G. G. (2011). Can a stock exchange improve corporate behavior? Evidence from firms' migration to premium listings in Brazil. Journal of Corporate Finance, 18(1), 20-35. https://doi.org/10.1016/j. jcorpfin.2011.01.003

Giacosa, E., Broccardo, L., \& Rossi, M. (2016). The financial leverage in medium-sized companies: An Italian survey. International Journal of Globalisation and Small Business, 8(2), 101-116. https://doi.org/10.1504/IJGSB.2016.078788

Harjadi, D., Yuniawan, A., Abdurrahman, A., Dananjoyo, R., Filatrovi, E. W., \& Arraniri, I. (2020). Product characteristics, market competitive strategies, and SMEs performance: Testing their relationships. Journal of Asian Finance, Economics and Business, 7(10), 613-620. https://doi.org//jafeb.2020.vol7. no10.613

KFSC (Korea Financial Services Commission). (2018). Policy of capital market innovation through revitalization of KOSDAQ, press release, (1.11.)

KRX. (2018). KONEX 2018 Understanding KONEX.

KVCA (Korean Venture Captial Association). (2018). Venture Capital Market Brief.

Lerner, J. (2000). The government as venture capitalist: The longrun impact of the SBIR program. Journal of Private Equity, 3(2), 55-78. https://doi.org/10.3905/jpe.2000.319960 
Mauzu, N. B., \& Ogujiuba, K. O. (2020). Financing gap as an obstacle to environmental sustainability in Sub-Saharan Africa: Evidence from the fuelwood energy sector in Nigeria. Journal of Science Technology and Education, 8(2), 77-90. https://doi. org/10.1063/5.0009297

McKaskill, T. (2009). Raising Angel \& Venture Capital FinanceAn entrepreneur's guide to securing venture finance. Emmaus, PA: Breakthrough Publications.

Nguyen, D. D. (2020). The impact of environmental factors on the international harmonization process of accounting on SMEs: Evidence in Vietnam. Journal of Asian Finance, Economics and Business, 7(10), 641-649. https://doi.org/10.13106/ jafeb.2020.vol7.no10.641

Park, J.-H., Binh, K. B., \& Eom, K. S. (2016). The effect of listing switches from a growth market to a main board: An alternative perspective. Emerging Markets Review, 29, 246-273. https:// doi.org/10.1016/j.ememar.2016.08.006

Stiglitz, E. J., \& Weiss, A. (1981). Credit rationing in markets with imperfect information. American Economic Review, 71(3), 393-410.

Sumiati, S. (2020). Improving small business performance: The role of entrepreneurial intensity and innovation. Journal of Asian Finance, Economics and Business, 7(10), 211-218 https://doi. org/10.13106/jafeb.2020.vol7.n10.211

Rossi, M., \& Martini, E. (2019). Venture capitalists and value creation: The role of informal investors in the growth of smaller European firms. International Journal of Globalisation and Small Business, 10(3), 233-247. https://doi.org/10.1504/ IJGSB.2019.100123

Rossi, M. (2014). Capital structure of small and medium enterprises: The Italian case. International Journal of Globalisation and Small Business, 6(2), 130-144. https://doi.org/10.1504/ IJGSB.2014.066471

Rossi, M., \& Fattoruso, G. (2017). The EMH and the market anomalies: An empirical analysis on Italian stock market. International Journal of Managerial and Financial Accounting, 9(3), 222-241. https://doi.org/10.1504/IJMFA.2017.086689

Udell, G. F. (2015). Issues in SME access to finance. European Economy, 2, 61-74.

\section{Endnotes}

${ }^{1}$ Describing the capital market's current and past states is daunting even if we focus only on SMEs and startups because the market includes too many different financial entities and various associated trades. Thus, we focus on the capital market related to non-listed SMEs and startups.

${ }^{2}$ However, large non-listed firms often trade in the private capital market through mergers and acquisitions, corporate restructuring, and issuances of securities for investment. In doing so, they deal with PE funds, financial institutions, pension funds, other firms, industrial capital funds, foreign funds, and even governments.
${ }^{3}$ In Korea, the term "government-controlling finance system" is used to indicate that the government plays a dominant role in the financial and banking markets. The Korean government has effectively controlled most of the private capital markets for a long time, and, thus, this term has a very negative connotation.

${ }^{4}$ Despite the KRX's identity as a private firm, which is strong enough that even Korean investors often mistakenly identify it as a public company, the Korean government strongly influences its business. Several previous studies describe the trading mechanism, financial system, financial products, and roles of the KRX.

${ }^{5}$ Among the financial derivatives traded on KRX exchanges are futures and options based on the KOSPI 200; their trading volume is among the highest in the world. Additionally, futures and options based on individual stocks, interest rates, and currencies are actively traded, as are fixed income instruments, such as government and stock-related bonds.

${ }^{6}$ The name "KOSDAQ," like the names "JASDAQ" in Japan and "CHASDAQ" in China, is based on the name "NASDAQ" in the U.S. All of these markets are new stock trading markets or platforms that facilitate financing for SMEs, including startups and venture enterprises. Although the KOSDAQ exchange was legally an over-the-counter market at its founding, investors could easily trade with each other. Thus, the KOSDAQ and the regular stock exchange were not discernably different.

${ }^{7}$ For more details, refer to the KRX website.

${ }^{8}$ Additionally, the Korea Over-the-Counter (K-OTC) board provides an over-the-counter market for stock trades; it is run by the Korea Financial Investment Association, which represents brokers and dealers. The KOSDAQ was run by the Korea Securities Dealers Association (KSDA) when it was first established. When several laws on securities markets and trading were later reorganized and unified, however, the KOSDAQ was merged into the KRX. This newly unified law, called "The Capital Market (Integration) Act," has been enforced since February 2009.

${ }^{9}$ In exceptional cases, the bond covenant specifies prepayment conditions. Bondholders can require early payments only if the covenant includes this additional contract.

${ }^{10} \mathrm{We}$ acknowledge that banks play a significant role in providing capital for SMEs and startups and that bank loans provide most of the capital raised by such firms. However, institutional finance differs from market-based finance, and, thus, we do not cover the banking sector as the primary capital-raising mechanism for SMEs and startups.

${ }^{11} \mathrm{PE}$ can be classified as leveraged buyouts, mezzanine capital, VC, and distressed debt investments. Two representative laws define VC in Korea: "The Support for Small and Medium Enterprise Establishment Act" along with the "Enforcement Decree of the Specialized Credit Financial Business Act" and the "Capital Market Act." The former defines the VC organizations that invest in startups, and the latter defines the organizations that invest in PE and are involved in various type of trades, such as buyouts, M\&As, restructuring, mezzanine capital investments, distressed debt investments, and VC investments. 
${ }^{12}$ The manager firms of the SME Parent Fund and the Growth Ladder Fund are the Korea Venture Investment Corporation (KVIC) and the Korea Growth Investment Corporation (K-Growth), respectively. These manager firms are government-owned companies.

${ }^{13}$ Lerner (2000) empirically analyzes the effects of the U.S. government's Small Business Innovation Research program using the matched sample difference technique. He argues that governmental public $\mathrm{VC}$ investments attract more private $\mathrm{VC}$ and that companies with injected governmental capital grow significantly faster through private $\mathrm{VC}$ in the long run than matched firms do. Using cross-country data, Brander, $\mathrm{Du}$, and Hellman (2015) provide evidence that a mix of governmental and private VC accelerates the IPOs or M\&As of invested firms.

${ }^{14}$ For simplicity, we convert KRW 1,000 into USD 1.

${ }^{15} \mathrm{On}$ average, 600 to $700 \mathrm{firms}$ are listed on the KOSPI, which is a major stock exchange.

${ }^{16}$ Korea Financial Services Commission (2018.1.11)

${ }^{17}$ The KOSPI's listing requirements are much stricter than the KOSDAQ's requirements. Park, Binh, and Eom (2016) show that moving from the KOSDAQ to the KOSPI generates no meaningful improvements with respect to stock price, volatility, and stock trade quality. De Carvalho and Pennacchi (2011) find that moving from the Brazilian stock market to the U.S. stock market, which is stringently regulated to protect shareholders, alters corporate behavior, leading to increases in stock trading volumes and prices.

${ }^{18}$ Professional or qualified investors are defined by the Capital Market Act.

${ }^{19}$ Although the requirement to submit a preliminary prospectus is intended to protect investors, it also imposes considerable costs on listing firms.

${ }^{20}$ SPACs' business areas have widened owing to the KONEX.

${ }^{21}$ Corporate bonds are converted into CBOs when they are first issued, which is why these securities are called P-CBOs. When previously issued and traded corporate bonds are reissued as $\mathrm{CBO}$ in the secondary market, they are called secondary CBOs.

${ }^{22}$ The KODIT and the KIBO can be classified as quasi-government agencies. For convenience, we describe them as government guarantee agencies. 